1001001110000 00100010101000 00001000100 11001001

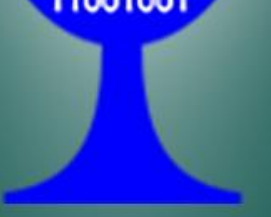

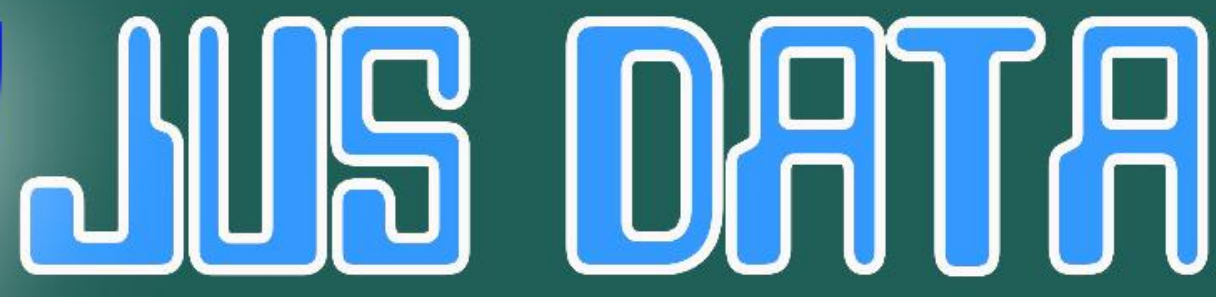

\section{Jurnal Sistem Informasi}
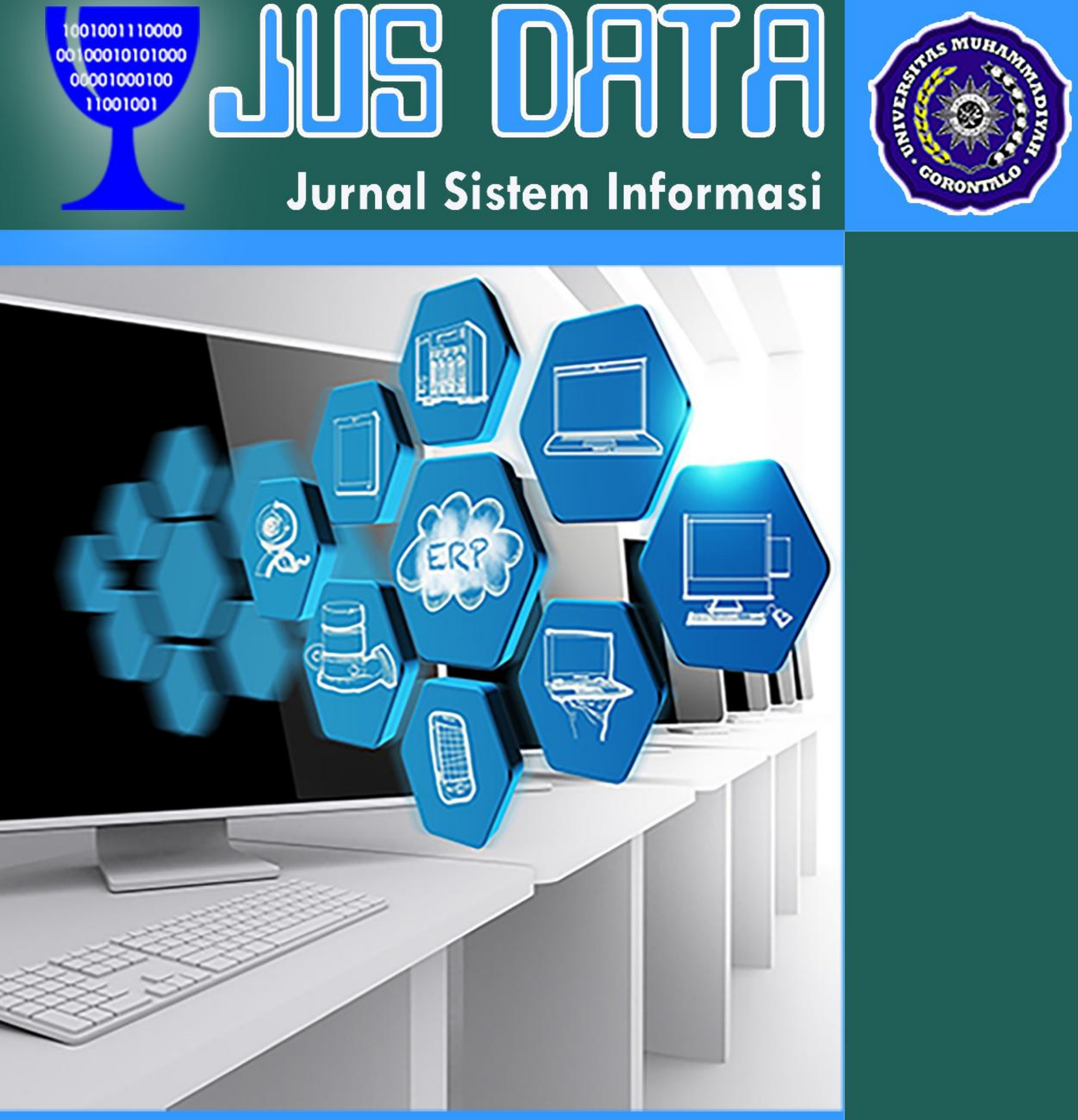

ISSN : 2301-5748 Volume : $5 \quad$ Nomor : $2 \quad$ Desember 2017

PROGRAM STUDI SISTEM INFORMASI UNIVERSITAS MUHAMMADIYAH GORONTALO 


\section{DAFTAR ISI}

ALGORITMA K-NEAREST NEIGHBOR BERBASIS FORWARD SELECTION UNTUK PREDIKSI RENTET WAKTU EKSPOR JAGUNG

Rubiyanto Maku, Edi Noersasongko

PREDIKSI MUATAN KARGO MENGGUNAKAN ALGORITMA K-NEAREST

NEIGHBOR BERBASIS FORWARD SELECTION

Irawan Ibrahim, Abdul Syukur.

KLASIFIKASI PENGADUAN MASYARAKAT MENGGUNAKAN

NAIVE BAYES BERBASIS SELEKSI ATRIBUT INFORMATION GAIN

Alter Lasarudin, Edi Noersasongko

APLIKASI COMPUTER VISION UNTUK PENENTUAN POSISI

OBJEK KOTAK PERSEGI PANJANG PADA RUANG TIGA DIMENSI

Rizal Lamusu, S.Kom, MT

SISTEM AKUNTANSI JASA DAN DAGANG TERPADU

Syahrial, M.Kom

OPTIMALISASI JARINGAN SYARAF TIRUAN MENGGUNAKAN PARTICLE

SWARM OPTIMIZATION UNTUK MEMPREDIKSI HASIL PRODUKSI

PERIKANAN TANGKAP

Wahyudin Hasyim, M.Kom 


\title{
SISTEM AKUNTANSI JASA DAN DAGANG TERPADU
}

\author{
Syahrial, M.Kom \\ Program Studi Sistem Informasi, Fakultas Sains Teknologi Universitas Muhammadiyah \\ Email: syahrial@umgo.ac.id
}

\begin{abstract}
Abstrak
Sistem informasi akuntansi menjadi alat komunikasi dalam berbisnis. Setiap organisasi menganggap penerapan akuntansi dalam organisasi merupakan keharusan. Masalah yang umumnya dihadapi oleh setiap organisasi adalah pengelolaan akuntansi masih secara konvensional. Perkembangan teknologi telah membawa hal baru berupa sistem informasi akuntansi. Bentuk pengelolaan yang terkomputerisasi telah menjadi keharusan dalam pengelolaan keuangan setiap organisasi. Pentingnya pengembangan sistem akuntasi telah diangkat dalam penelitian-penelitian sebelumnya. Penelitian mengenai pengembangan sistem informasi akuntansi telah dilakukan namun memiliki kekurangan berupa ruang lingkup yang masih terbatas pada satu atau dua bidang pengelolaan keuangan saja. Berdasarkan permasalahan yang ada maka perlu untuk dibangun sistem akuntansi jasa dan dagang yang terintegrasi atau terpadu dengan memadukan segala fasilitas dari sistem sebelumnya. Solusi yang diberikan dengan membangun sistem keuangan berbasis akuntansi dengan menggunakan bahasa C\# pada teknologi .Net Framework 4.0 dan penggunaan database MySQL server.
\end{abstract}

Kata kunci: Sistem informasi, Akuntansi Dagang, Akuntansi Jasa

\section{PENDAHULUAN}

Akuntansi sangat diperlukan dalam pengelolaan keuangan suatu lembaga atau perusahaan. Akuntansi sebagai alat komunikasi dalam berbisnis. Perkembangan teknologi telah membawa hal baru berupa sistem informasi akuntansi. Bentuk pengelolaan yang terkomputerisasi telah menjadi keharusan dalam pengelolaan keuangan setiap organisasi.

Pentingnya pengembangan sistem akuntasi telah diangkat dalam penelitianpenelitian sebelumnya. Penelitian sistem informasi dalam efektifitas penggunaan sistem informasi akuntansi dilakukan oleh [1] yang menunjukkan efektifitas yang baik. Selanjutnya oleh [2] menunjukkan pengaruh kualitas sistem informasi dan kualitas informasi akuntansi baik terhadap kepuasan pengguna software akuntansi secara simultan sebesar $89.8 \%$. Sistem informasi akuntansi juga berpengaruh positif pada keefektifan pengendalian internal kinerja karyawan dengan DUPL $=$ AUPL adalah 5\% [3]. Hal tersebut dapat menjadi rujukan bahwa sistem informasi sangat penting dalam efektifitas pengelolaan keuangaan, pengendalian internal dan kepuasan pengguna ditentukan oleh kualitas sistem informasi. Juga dalam hasil penelitian [4] menunjukkan bahwa penggunaan sistem akuntansi manajemen berpengaruh signifikan pada keberlangsungan hidup perusahaan.

Penelitian mengenai pengembangan sistem informasi akuntansi telah dilakukan oleh [5] berupa rancangan sistem informasi akuntansi penggajian. Sistem akuntansi lain diteliti oleh [6] mengenai sistem informasi penjualan berbasis akuntansi. Sistem penjualan tunai berbasis akuntasi diteliti oleh [7]. 
Penelitian mengenai sistem informasi akuntansi yang bersifat umum dilakukan oleh [8]. Mengananisis proses bisnis perusahaan yang paling pokok adalah proses pembelian dan persediaan bahan baku [9]. Pengembangan desain sistem informasi akuntansi pada usaha kecil dan menengah [10]. Perancangan sistem informasi akuntansi penjualan dan persediaan [11]. Sistem informasi akuntansi oleh [12]. Semua penelitian pengembangan sistem ini sudah baik namun memiliki kekurangan berupa ruang lingkup yang masih terbatas pada satu atau dua bidang pengelolaan keuangan saja.

Berdasarkan uraian diatas tentang permasalahan yang ada pada pembahasan sebelumnya serta berdasarkan penelitianpenelitian sebelumnya maka perlu untuk dibangun sistem akuntansi jasa dan dagang yang terintegrasi atau terpadu dengan memadukan segala fasilitas dari sistem sebelumnya. Sistem terpadu ini dapat menjadi rujukan untuk mengimplementasikan pengelolaan akuntansi pada lembaga pemerintahan maupun swasta yang terkomputerisasi..

\section{TINJAUAN PUSTAKA}

\subsection{Sistem Akuntansi}

Akuntansi didefenisiskan sebagai bahasa bisnis yang digunakan setiap organisasi sebagai komunikasi saat berbisnis [13]. Berdasarkan pengertian tersebut maka masyarakat menganggap menerapkan akuntansi merupakan keharusan dalam organisasi perusahaan.

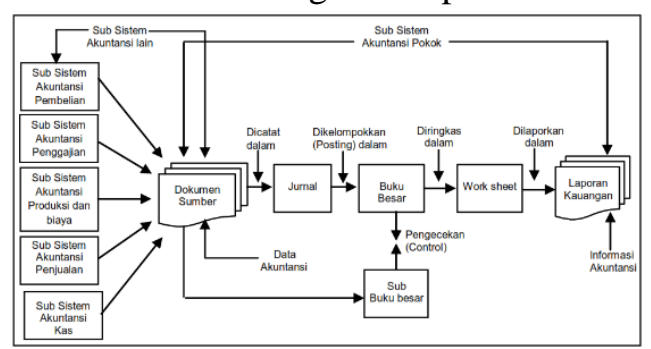

Gambar 1 Diagram Sistem Akuntansi (Susanto, 2017)
Dari gambar diatas memperlihatkan alur proses sistem akuntansi pada umumnya. Sistem akuntansi terbagi kedalam 2 (dua) sub sistem yaitu: akuntansi pokok dan akuntansi lain. Alur mulai dari akuntansi lain bersumber dari sub sistem-sub sistem yang ada ke akuntansi pokok berupa dokumen sumber yang dicatat dalam jurnal. Selanjutnya jurnal dikelompokkan dalam buku besar yang dilakukan pengecekan dengan sub buku besar. Buku besar dilakukan proses peringkasan dalam worksheet yang dilaporkan pada masingmasing laporan keuangan.

\subsection{Sistem Informasi Akuntansi}

Pengertian sistem informasi akuntansi adalah suatu subsistem proses transaksi keuangan dan transaksi nonkeuangan yang memiliki dampak langsung proses transaksi keuangan [14]. Pengertian lainnya sistem informasi akuntansi merupakan sistem yang mengoleksi, merekam, menyimpan dan memproses data untuk menyediakan informasi untuk menentukan pilihan [15].

Akuntansi pada dasarnya merupakan sistem informasi, yang membedakan akuntansi sebagai sistem informasi dengan sistem informasi perusahaan lainnya adalah sistem informasi (akuntansi) atau disebut juga sebagai sistem informasi akuntansi hanya berkaitan dengan fungsi akuntansi dalam mengolah data tentang aktivitas organisasi perusahaan yang memiliki nilai ekonomi. Jadi sistem informasi akuntansi (SIA) hanya mengolah data yang memiliki dampak ekonomi. Kebanyakan dari data akuntansi yang diolah oleh SIA disajikan dalam bentuk jumlah uang atau bentuk lain yang terkait atau dapat dikonversikan kedalam jumlah uang [13].

Fungsi/peran sistem informasi akuntansi adalah sebagai berikut [13]: 
a. Mendukung aktivitas sehari-hari perusahaan:

b. Mendukung proses pengambilan keputusan

c. Membantu dalam memenuhi tanggung jawab pengelolaan perusahaan.

\section{METODOLOGI}

Tahapan penelitian digambarkan pada gambar 3.1 dibawah.

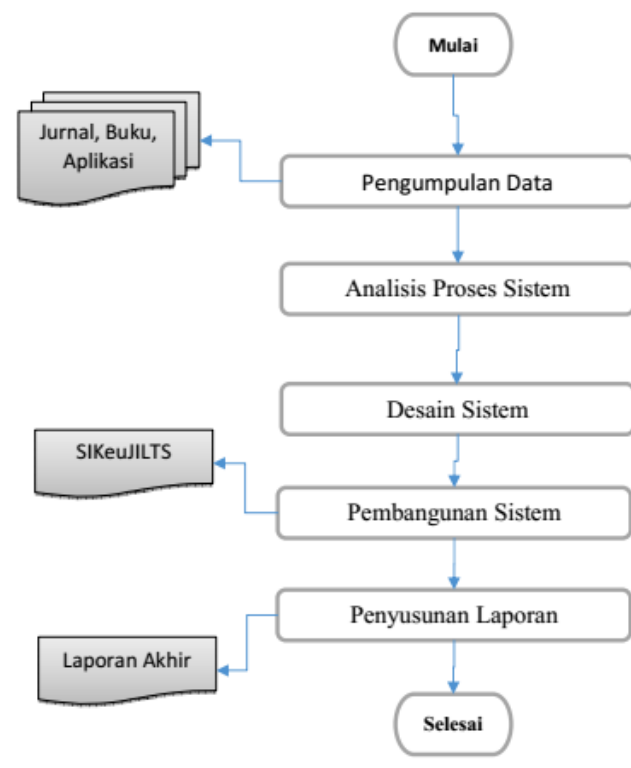

Gambar 1 Tahapan Penelitian

Metode yang digunakan pada penelitian ini adalah metode penelitian eksperimen dengan menggunakan metode pengembangan sistem prototype. Peneliti menyesuaikan metode pengembangan sistem prototype sesuai kebutuhan.

\section{HASIL DAN PEMBAHASAN 4.1 Pengumpulan Data}

Kepustakaan digunakan untuk mencari literatur-literatur yang berhubungan dengan pengelolaan keuangan. Pengumpulan data digunakan untuk mendapatkan arsitektur sistem informasi akuntansi dari hasil pengembangan dalam penelitian sebelumnya.

\subsection{Analisis Proses Sistem}

a. Kebutuhan Fungsional

Berdasarkan data yang didapat pada tahapan pengumpulan data, peneliti mengidentifikasi kebutuhan fungsional sistem akuntansi terpadu.

Tabel 3.1 Daftar Kebutuhan Fungsional Sistem.

\begin{tabular}{|c|c|c|c|c|c|}
\hline No. & Fungsional & Masukan & Proses & Keluaran & Ket. \\
\hline 1. & $\begin{array}{l}\text { Dapat mengelolah data } \\
\text { golongan }\end{array}$ & \begin{tabular}{|l|} 
Data golongan \\
\end{tabular} & \begin{tabular}{|l} 
Simpan, Update, \\
Delete
\end{tabular} & Informasi: golongan & \\
\hline 2. & Dapat mengelolah data akun & Data akun & $\begin{array}{l}\text { Simpan, Update, } \\
\text { Delete }\end{array}$ & Informasi: akun & \\
\hline 3. & Mampu mengelolah data jurnal & Data jurnal & \begin{tabular}{|l|} 
Simpan, Update, \\
Delete
\end{tabular} & Informasi: jurnal & \\
\hline 4. & $\begin{array}{l}\text { Mampu mengelolah data } \\
\text { piutang }\end{array}$ & Data jurnal & \begin{tabular}{|l} 
Simpan, Update, \\
Delete
\end{tabular} & Informasi: piutang & \\
\hline 5. & $\begin{array}{l}\text { Dapat mengelolah data } \\
\text { inventaris }\end{array}$ & $\begin{array}{l}\text { Data jurnal dan data } \\
\text { penyusutan }\end{array}$ & \begin{tabular}{|l} 
Simpan, Update, \\
Delete
\end{tabular} & $\begin{array}{l}\text { Informasi: inventaris, } \\
\text { penyusutan }\end{array}$ & \\
\hline 6. & $\begin{array}{l}\text { Sistem dapat diakses dari multi } \\
\text { platform atau multi sistem } \\
\text { informasi. }\end{array}$ & $\begin{array}{l}\text { Sistem berbasis } \\
\text { dekstop }\end{array}$ & $\begin{array}{l}\text { C\#, MySQL, dan } \\
\text {.Net Framework } \\
4.0\end{array}$ & File Executable & \\
\hline
\end{tabular}

Pada tabel di atas berupa daftar kebutuhan fungsional yang harus dipenuhi oleh sistem informasi klinik terpadu. Kebutuhan tersebut diatas dijabarkan masukan, proses yang dapat dilakukan, serta keluaran dari masing-masing fungsional tersebut.

Tabel 3.2 Daftar Ekstenal Entity.

\begin{tabular}{|c|c|l|l|l|l|}
\hline No. & Entity & Masukan & Proses & \multicolumn{1}{|c|}{ Keluaran } & Ket. \\
\hline 1. & Bendahara & $\begin{array}{l}\text { Data } \\
\text { golongan, } \\
\text { akun, } \\
\text { jurnal, } \\
\text { penyusuta } \\
\text { n, data } \\
\text { pengguna }\end{array}$ & $\begin{array}{l}\text { Simpan } \\
\text { Update, } \\
\text { Delete }\end{array}$ & $\begin{array}{l}\text { Informasi: } \\
\text { jurnal, } \\
\text { cashflow, } \\
\text { neraca } \\
\text { saldo, laba } \\
\text { rugi, } \\
\text { perubahan } \\
\text { modal, } \\
\text { neraca akhir }\end{array}$ & \\
\hline 2. & Admin & $\begin{array}{l}\text { Data } \\
\text { pengguna, } \\
\text { ekspedisi }\end{array}$ & $\begin{array}{l}\text { Simpan } \\
\text { Update, } \\
\text { Delete }\end{array}$ & $\begin{array}{l}\text { Informasi: } \\
\text { Transaksi }\end{array}$ & \\
\hline 3. & Manager & $\begin{array}{l}\text { Data } \\
\text { pengguna }\end{array}$ & Load & $\begin{array}{l}\text { Informasi: } \\
\text { cashflow, } \\
\text { neraca } \\
\text { saldo, laba } \\
\text { rugi, } \\
\text { perubahan } \\
\text { modal, } \\
\text { neraca } \\
\text { akhir, } \\
\text { informasi } \\
\text { transaksi }\end{array}$ & \\
& & & & \\
\end{tabular}

Pada tabel 3.2 memperlihatkan identifikasi eksternal entity berdasarkan masukan, interaksi proses yang dapat dilakukan, dan keluaran dari sistem yang dapat dilihat.

b. Kebutuhan Non-Fungsional

Berdasarkan identifikasi kebutuhan fungsional sebelumnya, peneliti mengidentifikasi kebutuhan nonfungsional sistem akuntansi jasa dan dagang terpadu sebagai penunjang sistem yang dirangkum dalam tabel 3.3. Terdapat 3 kebutuhan non fungsional yang diidentifikasi yaitu: web server, MySQL server, dan komputer. 
Tabel 5.4 Daftar Kebutuhan Non Fungsional Sistem.

\begin{tabular}{|c|c|c|c|c|}
\hline No & $\begin{array}{c}\text { Kebut } \\
\text { uhan }\end{array}$ & $\begin{array}{c}\text { Spesifika } \\
\text { si }\end{array}$ & Manfaat & $\begin{array}{c}\text { Minimu } \\
\mathrm{m}\end{array}$ \\
\hline 1. & $\begin{array}{l}\text { Web } \\
\text { Server }\end{array}$ & HTTP & $\begin{array}{l}\text { Sebagai server } \\
\text { tempat berjalan } \\
\text { aplikasi }\end{array}$ & $\begin{array}{l}\text { Apache } \\
2 \text { atau } \\
\text { setara }\end{array}$ \\
\hline 2. & $\begin{array}{l}\text { MySQ } \\
\text { L }\end{array}$ & $\begin{array}{l}\text { SQL, } \\
\text { relasi } \\
\text { data }\end{array}$ & $\begin{array}{l}\text { Mengelolah dan } \\
\text { menyimpan data } \\
\text { secara berelasi }\end{array}$ & $\begin{array}{l}\text { MySQL } \\
\text { Server } \\
5.5 \text { atau } \\
\text { setara }\end{array}$ \\
\hline 3. & $\begin{array}{l}\text { Komp } \\
\text { uter }\end{array}$ & $\begin{array}{l}\mathrm{x} 86 / \\
\text { x64, } \\
\text { memory } \\
\text { DDR2 } \\
\text { hardisk } \\
\text { 5000rpm }\end{array}$ & $\begin{array}{l}\text { Sebagai tempat } \\
\text { berjalan aplikasi } \\
\text { dan penyimpanan } \\
\text { fisik }\end{array}$ & $\begin{array}{l}\text { Intel } \\
\text { Pentiu } \\
\text { m Core } \\
2 \text { Duo, } \\
512 \\
\text { MB, } \\
20 \text { GB }\end{array}$ \\
\hline
\end{tabular}

\section{Desain Proses Sistem}

Pada gambar 3.2 menunjukkan diagram konteks dengan entitas eksternal yang berinteraksi dengan sistem berdasarkan aliran data masing-masing.

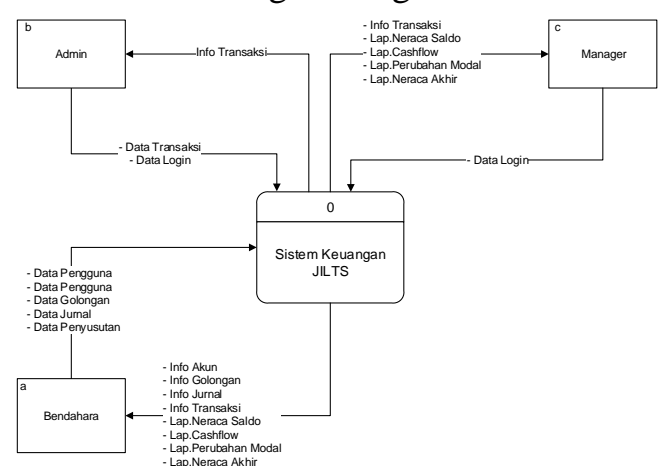

Gambar 3.2 Diagram Konteks ePoliklinik.

Pada gambar 3.3 menunjukkan diagram HIPO (Hierarchycal Input Process Output) dengan e-Poliklinik sebagai proses utamanya dan diturunkan menjadi beberapa level proses.

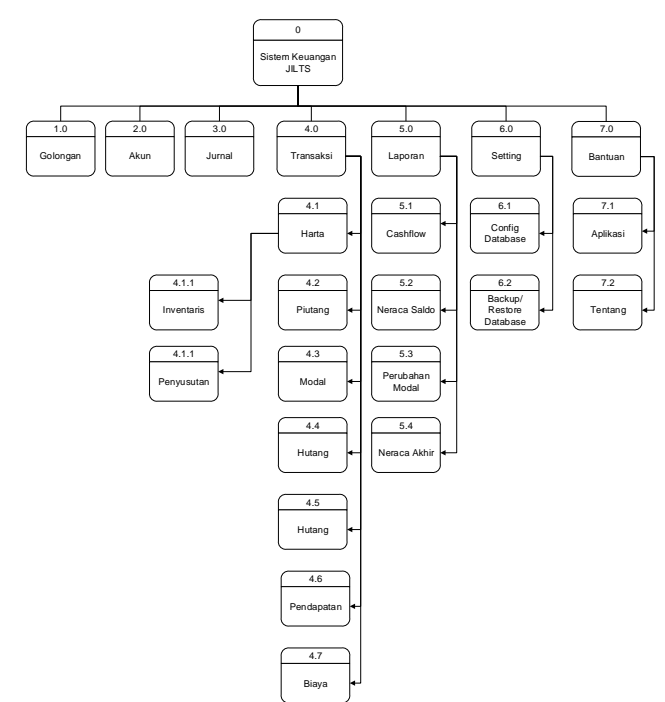

Gambar 3.3 Diagram HIPO atau Berjenjang SIKeuJILTS

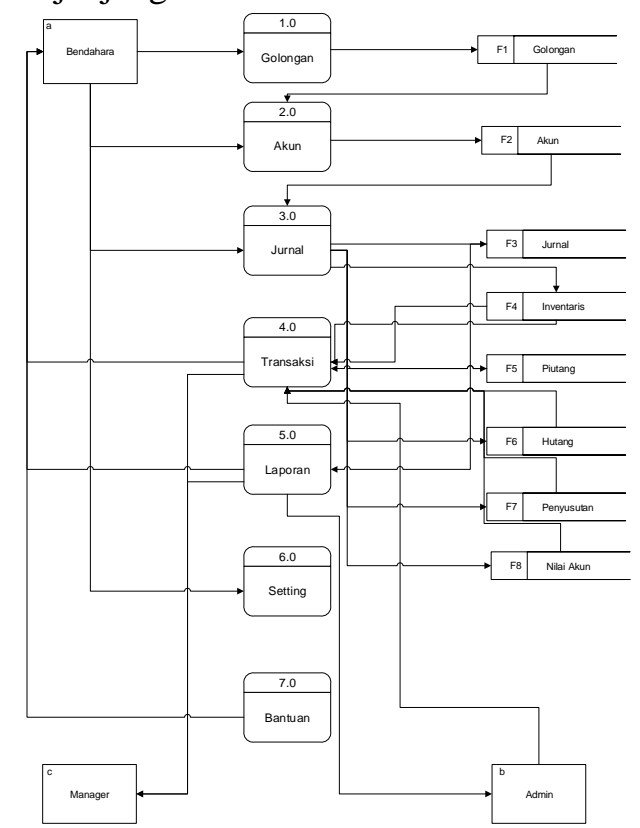

Gambar 3.3 Diagram DFD Level 0 SIKeuJILTS

\section{Pembangunan Sistem}

Hasil pembangunan sistem dibuat HTML5 memanfaatkan template Clinico dengan bahasa pemrograman PHP serta MySQL Server 5.6. 


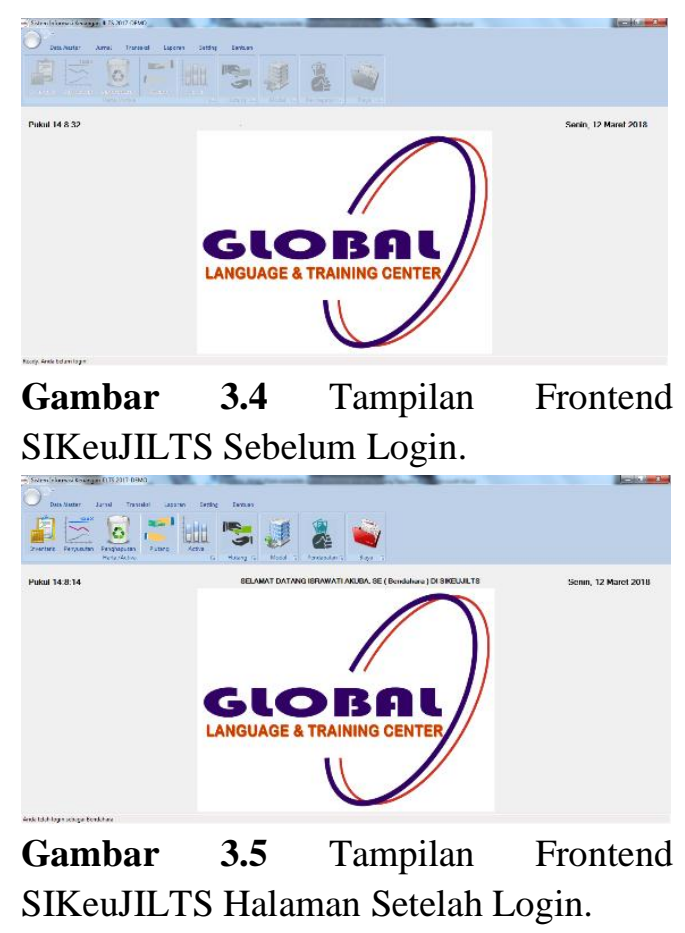

\section{KESIMPULAN DAN SARAN}

Aplikasi sistem SIKeuJILTS dapat menampilkan informasi berupa keadaan keuangan saat ini berupa neraca saldo, data transaksi, dan laporan laba-rugi. Aplikasi ini dapat memberikan informasi data transaksi berupa piutang, hutang, modal, pendapatan, dan biaya Aplikasi ini dapat mempermudah pengelolaan piutang dan inventaris. Aplikasi ini dapat menjadi sarana pengelolaan keuangan yang terpadu.

Perlu dikembangkan dengan memanfaatkan teknologi web, perubahan tampilan, dan perubahan laporan yang mengikuti standar akuntansi. Perlu dibuatkan aplikasi yang berbasis teknologi mobile.

\section{DAFTAR PUSTAKA}

[1] N. Widyasari, "Analisis Efektifitas Sistem Informasi Akuntansi Penggajian Karyawan Pada RSUD Kota Semarang," Fakultas Ekonomi
Universitas Diponegoro - Tidak

Diterbitkan, Semarang, 2012.

[2] T. Saleh, Darwanis dan U. Bakar, "Pengaruh Kualitas Sistem Informasi Terhadap Kualitas Informasi Akuntansi Dalam Upaya Meningkatkan Kepuasan Pengguna Software Akuntansi Pada Pemerintah Aceh," Jurnal Akuntansi Pascasarjana Universitas Syiah Kuala, Volume 2, No. 1, ISSN 23020164, pp. 110-124, 2012.

[3] D. Efendi, "Pengaruh Sistem Informasi Akuntansi Dan Kinerja Karyawan Terhadap Keefektifan Pengendalian Internal Di KOPERINDO Jatim Cabang Nganjuk," Cahaya Aktiva Vol.03 No.2, ISSN : 2302 - 240X, pp. 72-80, 2013.

[4] D. Kurnia, "Analisis Sistem Akuntansi Manajemen Pada Perusahaan Manufaktur Di Kabupaten Serang Implikasinya Pada Kelangsungan Hidup (Going Concern) Perusahaan," Jurnal Akuntansi. Vol 2 No. 1, ISSN 23392436, pp. 86-102, 2015.

[5] Kriswanto, "Analisis Sistem Informasi Akuntansi Penggajian Pada PT XYZ," BINUS BUSINESS REVIEW, Vol. 4 No. 2, pp. 865-878, 2013.

[6] R. Yunanto, A. Muchtar dan D. W. Firdaus, "Implementasi Sistem Informasi Penjualan Berbasis ClientServer," Jurnal Riset Komputerisasi Akuntansi, Vol. 1, No. 1, pp. 21-40, 2012.

[7] A. Wicaksono, "Perancangan Sistem Akuntansi Penjualan Tunai Terkomputerisasi Pada Al Ishba Karpet," Jurnal Nominal,Volume I, Nomor I, pp. 30-33, 2012. 
[8] K. Rahayu, "Pembuatan Sistem Informasi Akuntansi Pada Toko Bangunan "X" Berbasis Web," Calyptra: Jurnal Ilmiah Mahasiswa Universitas Surabaya Vol.2 No.2, pp. 1-10, 2013.

[9] H. Juwitasary, M. Martani dan A. N. G. Putra, "Analisis Sistem Informasi Akuntansi Pembelian Dan Persediaan Pada PT. XYZ," ComTech Vol. 6 No. 1, pp. 96-108, 2015.

[10] N. Aini dan L. Rifani, "Pengembangan Desain Sistem Informasi Akuntansi Pada Usaha Kecil Dan Menengah Kampung Roti Surabaya," dalam Seminar Nasional Sistem Informasi Indonesia SESINDO, 2-3 November 2015, Surabaya, 2015.

[11] D. Prakasita, "Perancangan Sistem Informasi Akuntansi Penjualan Dan Persediaan Di Central Steak And Coffee Boyolali," Skripsi Program Studi Akuntansi Fakultas Ekonomi Universitas Negeri Yogyakarta Tidak Diterbitkan, Yogyakarta, 2015.

[12] D. Sugiarto dan A. Wibowo, "Sistem Informasi Akuntansi pada PT. Jape Dilijaya," Skripsi Program Studi Teknik Informatika Fakultas Teknologi Industri Universitas Kristen Petra - Tidak Diterbitkan, Surabaya, 2017.

[13] A. Susanto, Sistem Informasi Akuntansi - Pemahaman Konsep Secara Terpadu, Bandung: Lingga Jaya, 2017.

[14] J. A. Hall, Introducing to Accounting Information Systems (7th edition), New York: McGraw-Hill, 2008.
[15] M. Romney dan P. Steinbart, Accounting Information Systems, Edinburgh: Pearson, 2015.

[16] MENKES, SK MENKES, Jakarta: MENKES, 1992.

[17] R. V. Imbar dan Y. Kurniawan, "Perancangan Sistem Informasi Pelayanan Medis Rawat Jalan Poliklinik Kebidanan dan Kandungan pada RSUD Kota Batam," Jurnal Sistem Informasi, Vol.7, No.1, pp. 53-67, 2012.

[18] R. E. I. Bagaskara, W. A. Syafei dan R. R. Isnanto, "PERANCANGAN SISTEM INFORMASI POLIKLINIK," TRANSIENT, VOL.1, NO. 4, ISSN: 2302-9927, 349, pp. 1-7, 2012.

[19] M. Andriyas, "Rancang Bangun Sistem Informasi Laboratorium Klinik Berbasis Web Pada Laboratorium Klinik Utama SAFIRAH Sidoarjo," Jurusan Sistem Informasi, Sekolah Tinggi Manajemen Informatika dan Teknik Komputer Surabaya- Tidak diterbitkan, Surabaya, 2012.

[20] B.

B. Budiawan, "PEMBANGUNAN SISTEM INFORMASI KLINIK GIGI DENTAL SMILE MENGGUNAKAN FRAMEWORK CODEIGNITER," Tugas Akhir Prodi Teknik Informatika, Fakultas Teknologi Industri, Universitas Atma Jaya - Tidak Diterbitkan, Yogyakarta, 2013.

[21] R. R. M. Salim, "PENGEMBANGAN SISTEM INFORMASI KLINIK BERBASIS WEB," dalam Seminar Nasional Sistem Informasi Indonesia, 2013.

[22] S. A. Wuner, R. Sengkey dan O. A. Lantang, "ANALISA DAN 
PERANCANGAN

SISTEM INFORMASI POLIKLINIK

UNSRAT BERBASIS WEB,” 2014.

[23] B. S. Prakoso, "SISTEM INFORMASI ADMINISTRASI KLINIK NGUDI WARAS PURWODADI BERBASIS WEB," Makalah PROGRAM STUDI TEKNIK INFORMATIKA FAKULTAS KOMUNIKASI DAN INFORMATIKA UNIVERSITAS MUHAMMADIYAH

SURAKARTA - Tidak Diterbitkan, Surakarta, 2014.

[24] A. H. Arrosid, "SISTEM INFORMASI POLIKLINIK PADA KLINIK CITO INDRAPASTA SEMARANG," Skripsi Program Studi Sistem Informasi, Fakultas Ilmu Komputer Universitas Dian Nuswantoro - Tidak Diterbitkan, Semarang, 2014.

[25] E. S. Sumariani, "ANALISIS KEBUTUHAN PERENCANAAN SISTEM INFORMASI KESEHATAN PADA BIDANG PELAYANAN DINAS KESEHATAN KABUPATEN BOYOLALI," Artikel PROGRAM STUDI KESEHATAN MASYARAKAT FAKULTAS ILMU KESEHATAN

UNIVERSITAS

MUHAMMADIYAH

SURAKARTA - Tidak Diterbitkan, Surakarta, 2015.

[26] R. Sutjiadi, "Perancangan dan Pembuatan Aplikasi Sistem Klinik Berbasis Web (Studi Kasus Klinik dr. Rida)," Jurnal TEKNIKA, pp. 3543, 2015.

[27] Tominanto, "PERANCANGAN SISTEM INFORMASI PENDAFTARAN RAWAT JALAN
KLINIK,” Jurnal Manajemen Informasi Kesehatan Indonesia Vol. 3 No.2, SSN: 2337-6007 (online); 2337-585X (Printed), pp. 32-38, 2015.

[28] I. P. A. Y. Permana, "Rancang Bangun Sistem Informasi Klinik Praktik Dokter Berbasis Web," Jurnal Teknologi Informasi dan Komputer, Volume1, Nomor 2, pp. 127-133, 2015.

[29] U. A. Faruq, "RANCANG BANGUN APLIKASI REKAM MEDIS POLIKLINIK UNIVERSITAS TRILOGI," JURNAL INFORMATIKA Vol. 9, No. 1, pp. 1017-1027, 2015.

[30] A. S. Maryati, S. K. Sari dan A. P. Kurniawan, "SISTEM INFORMASI KLINIK BHAKTI SEHAT BERBASIS WEB," dalam $e$ Proceeding of Applied Science : Vol.1, No.3, ISSN : 2442-5826, 2015.

[31] R. Sinaga dan Nurhadi, "ANALISIS DAN PERANCANGAN SISTEM INFORMASI REKAM MEDIS PADA KLINIK AKPER KESDAM II/SRIWIJAYA GARUDA PUTIH," Jurnal Manajemen Sistem Informasi Vol 1 No. 1, ISSN : 2540-8011, pp. 67-79, 2016.

[32] Jogiyanto, Analisis \& Desain Sistem Informasi, Yogyakarta: Andi Offset, 2005.

[33] Loudon, dalam Sistem Informasi Manajemen Mengelola Perusahaan Digital, Jakarta, Pearson education, 2007, p. 15.

[34] MENKES, PERMENKES, Jakarta, 1989.

[35] Sjamsuhidajat, Manual rekam medis, Jakarta: Konsil Kedokteran Indonesia, 2006. 
[36] D. Dayani, "Penerapan Sistem Akuntansi Penerimaan Dan Pengeluaran Kas Pada BMT AsSalam," Tugas Akhir, Program Studi Akuntansi DIII, Fakulatas Ekonomi, Univeristas Negeri Yogyakarta Tidak Diterbitkan, Yogyakarta, 2013. 